\title{
Penerapan Metode Dynamic Cell Spreading (DCS) Untuk Menyembunyikan Teks Tersandi Pada Citra
}

\author{
${ }^{1}$ Marthin Edy Purnawan Laoli, ${ }^{2}$ Taronisokhi Zebua, M.Kom \\ ${ }^{1}$ Mahasiswa S1 Teknik Informatika Komputer STMIK Budi Darma Medan \\ ${ }^{2}$ Dosen Tetap STMIK Budi Darma Medan \\ Marthin.2.laoli@gmail.com
}

\begin{abstract}
Abstrak. Keamanan adalah sebuah keadaan yang ingin bebas dari segala bentuk serangan apapun dan bertujuan untuk melindungi data maupun informasi dari berbagai tindakan kejahatan cyber seperti yang dilakukan oleh para hacker dan cracker. Keamanan memiliki dua teknik yaitu kriptografi dan steganografi. Kombinasi kedua teknik tersebut dapat digunakan sebagai salah satu solusi untuk meningkatkan keamanan data maupun informasi yang bersifat rahasia, dimana teknik kriptografi digunakan untuk menyandikan pesan dan teknik steganografi digunakan untuk menyembunyikan pesan yang telah disandikan sebelumnya. Steganografi dapat dipandang sebagai kelanjutan kriptografi. Jika pada kriptografi, data yang telah disandikan (chipertext) tetap tersedia, maka dengan steganografi chipertext dapat disembunyikan sehingga pihak ketiga tidak mengetahui keberadaannya. Data rahasia yang disembunyikan dapat di ekstraksi kembali persis sama seperti keadaan aslinya. Kombinasi dari teknik kriptografi dan steganografi akan diterapkan dalam perancangan sebuah aplikasi keamanan data yang bisa digunakan untuk meningkatkan keamanan data atau informasi. Aplikasi yang telah siap dirancang, akan dapat dipergunakan untuk menyisipkan pesan rahasia ke dalam media penampung sehingga pesan rahasia yang telah dikirim akan sampai kepada penerima dengan utuh tanpa terjadi kerusakan pada pesan ataupun pada media penampungnya. Pada prakteknya, aplikasi yang telah dirancang harus dimiliki oleh kedua belah pihak. Baik pengirim maupun penerima.
\end{abstract}

Kata Kunci : Keamanan, Kriptografi, Steganografi, Citra, Pesan

\section{PENDAHULUAN}

Keamanan adalah sebuah keadaan yang ingin bebas dari segala bentuk serangan apapun dan bertujuan untuk melindungi data maupun informasi dari berbagai tindakan kejahatan cyber seperti yang dilakukan oleh para hacker dan cracker. Keamanan memiliki dua teknik yaitu kriptografi dan steganografi. Berdasarkan penelitian terdahulu yang dilakukan oleh Zulhadi Hasibuan, dengan judul penelitian "Perancangan Aplikasi Steganografi Dengan Metode Least Significant Bit (LSB) untuk data terenkripsi dari algoritma Hill Cipher", Penerbit : Pelita Informatika Budidarma, Volume : VI, Nomor : 2, April 2014, menyatakan bahwa Kritografi adalah suatu ilmu dan seni untuk menjaga kerahasiaan pesan dengan cara menyandikanya ke dalam bentuk yang tidak dapat dimengerti lagi maknanya. Teknik menjaga kerahasiaan data tidak hanya menggunakan kriptografi, teknik lain yang dapat digunakan yaitu steganografi. Steganografi adalah seni dan ilmu untuk menyembunyikan pesan rahasia didalam objek (Text, Audio, Video dan Image/Citra) lain sehingga keberadaan pesan rahasia tersebut tidak dapat diketahui.

Tujuan dari penelitian ini adalah untuk mengetahui prosedur pengamanan data teks dengan kombinasi teknik kriptografi dan steganografi, Menerapkan algoritma Hill Cipher dan Dynamic Cell Spreading (DCS) dalam mengamankan data teks serta untuk Merancang aplikasi penyembunyian teks tersandi pada sebuah citra berdasarkan teknik kriptografi dan steganografi.

\section{BAHAN DAN METODE}

\section{Bahan}

Bahan penelitian yang digunakan sebagai objek penelian adalah data teks sebagai objek yang akan disembunyikan, citra digital sebagai media penampung pesan. Pada proses encoding dan decoding diperlukan algoritma pada setiap teknik keamanan yang digunakan, diantaranya yaitu menggunakan algoritma Hill Cipher dalam melakukan proses enkripsi dan dekripsi serta menggunakan algoritma Dynamic Cell Spreading (DCS) dalam melakukan proses embedding dan extraction.

\section{Metode}

\section{Hill Cipher}

Hill chiper merupakan penerapan artimetika modulo pada kriptografi. Teknik kriptografi ini menggunakan sebuah matriks persegi sebagai kunci untuk melakukan enkripsi dan dekripsi. Hill cipher diciptakan oleh Lester S. Hill pada tahun 1929. Teknik kriptografi ini diciptakan dengan maksud membuat cipher yang tidak dapat dipecahkan dengan analisis frekuensi. Hill chiper menggunakan matriks untuk mentransformasikan string berupa blok huruf. Hill chiper berdasarkan pada aljabar linier dan seperti sandi vigenere, hill chiper merupakan 
block chiper. Sandi ini dapat dipecahkan dengan known-plaintext attack tetapi tahan melawan chipertext-only attack. Cara kerja sandi ini berdasarkan atas perkalian matriks dengan menggunakan sebuah kunci. Misalkan $\mathrm{m}$ adalah bilangan bulat positif dan $\mathrm{P}=\mathrm{C}=(\mathrm{Z} 26) \mathrm{m}$ dan misalkan $\mathrm{K}=\{\mathrm{m} \mathrm{x} \mathrm{m}$ merupakan matriks yang nilai elemennya terdiri dari Z26\} maka untuk suatu kunci $\mathrm{K}$, dapat didefenisikan sebagai $(\mathrm{x}) \bmod 26 \mathrm{dan} \mathrm{dk}(\mathrm{y})=\mathrm{k}-1$ y mode 26 dimana semua opersi dilakukan dalam matriks Z-26.

\section{Dynamic Cell Spreading}

Dynamic Cell Spreading (DCS) merupakan steganografi dengan menggunakan model proteksi terhadap deteksi yang dikembangkan oleh Holger Ohmacht dengan konsep dasar yaitu menyembunyikan file pesan (semua data eletronik) ke dalam media gambar (jpeg). Penyembunyian pesan dilakukan dengan cara menyisipkan pada bit rendah Least Significant Bit (LSB) dari data pixel yang menyusun file tersebut menggunakan buffer memori sebagai media penyimpanan sementara. Dalam proses penggabungan (stego) antara file gambar dengan teks, untuk file bitmap 24 bit maka setiap pixel (titik) pada gambar tersebut akan terdiri dari susunan tiga warna, merah (red), hijau (green) dan biru (blue) yang dikenal dengan RGB yang masing-masing disusun oleh bilangan 8 bit (byte) dari 0 sampai 255 atau dengan format biner 00000000 sampai 11111111.

\section{HASIL DAN PEMBAHASAN}

Proses Enkripsi Berdasarkan Hill Cipher. Proses yang dilakukan dalam penyandian (enkripsi) pesan berdasarkan algoritma hill cipher dilakukan dengan langkah-langkah berikut :

1. Siapkan teks utama yang akan disandikan

2. Siapkan kunci yang akan digunakan dalam melakukan penyandian

3. Lakukan pengubahan teks menjadi angka desimal berdasarkan tabel ASCII

4. Lakukan proses enkripsi data teks dengan menggunakan metode hill cipher dan modulus 256

5. Dari proses enkripsi tersebut akan menghasilkan suatu output yaitu ciphertext yang nantinya akan disisipkan ke dalam media penampung (citra digital).

Berikut ini contoh proses enkripsi terhadap pesan (plaintext), dimana plaintext tersebut adalah MARTHINLAOLI. Plaintext tersebut akan dienkripsi berdasarkan hill cipher dengan menggukan kunci matriks ordo 3x3, sehingga menghasilkan ciphertext. Ciphertext dari MARTHINLAOLI adalah $\neg \neq » \gg \ll \widetilde{O}^{\prime \prime}\left\{\tilde{\mathrm{A}}^{-}\right.$TMÎ.

Proses Embedding Berdasarkan Dynamic Cell Spreading (DCS). Proses yang dilakukan dalam penyisipan (embedding) pesan ke dalam sebuah citra cover berdasarkan algoritma dynamic cell spreading dilakukan dengan langkah-langkah berikut :

1. Siapkan pesan utama yang akan disembunyikan, kemudian setiap karakter pesan utama dikonversi menjadi biner, kemudian hitung total bit pesan utama.

2. Siapkan sebuah kunci steganografi yang digunakan untuk proses embedding maupun ekstraction dan sebuah karakter penanda akhir bit-bit pesan.

3. Lakukan proses XOR terhadap masing-masing karakter kunci, hasil akhir proses XOR akan dijadikan sebagai kunci proses embedding dan extraction.

4. Gabungkan biner kunci dengan biner penanda serta biner pesan utama.

5. Siapkan citra cover (sebagai media penapung)

6. Konversi nilai-nilai pixel citra cover menjadi biner

7. Kalkulasikan jumlah bit yang dapat ditampung oleh citra cover

Proses kalkulasi jumlah bit yang dapat ditampung oleh citra cover sangat penting dilakukan sebelum proses penyembunyian. Apabila jumlah bit pesan lebih besar dari jumlah bit citra cover akan menyebabkan tidak semua bit pesan dapat tersimpan di dalam citra cover.

8. Tentukan nilai m untuk dijadikan sebagai nilai awal modulus pembangkit bilangan acak.

9. Lakukan pengacakan terhadap pixel-pixel citra cover

Proses ini dilakukan dengan menentukan sebuah bilangan bulat positif yang digunakan sebagai nilai awal pembangkit bilangan-bilangan acak pengacak posisi-posisi pixel citra cover. Simpan pixel hasil pengacakan ke dalam memori sementara (buffer memory)

10. Lakukan proses penggantian bit-bit rendah (least significant bit) dari setiap elemen warna pixel citra cover hasil pengacakan yang telah disimpan di dalam buffer memory. Sebelum proses ini dilakukan, maka nilai-nilai pixel hasil pengacakan dirubah ke biner.

11. Susun kembali palet warna pixel citra cover teracak seperti susunan posisi-posisi pixel citra cover sebelum proses pengacakan dan petakan sebagai citra baru.

12. Simpan citra menjadi steganoimage. 
Berikut ini contoh proses embedding berdasarkan Dynamic Cell Spreading (DCS), dimana pada proses ini akan membutuhkan pesan dan citra cover sebagai media penampung pesan tersebut. Pesan yang digunakan pada proses ini adalah ciphertext yang telah dihasilkan dari proses enkripsi sebelumnya, yaitu $\neg \ddagger » » \ll \tilde{O}^{\prime} "\left\{\tilde{\mathrm{A}}^{-}\right.$TMÎ. Pesan tersebut akan disembunyikan didalam citra cover. Citra cover yang digunakan dapat dilhat pada gambar 1.

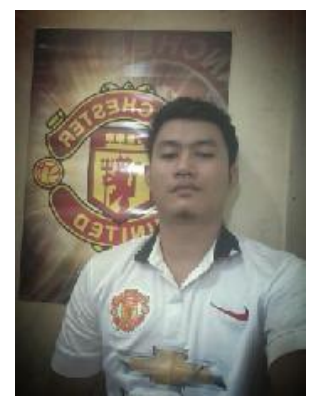

\section{Gambar 1.Citra Cover}

Setelah melakukan proses embedding atau penyembunyian pesan teks pada citra cover, maka akan menghasilkan citra stegano. Citra stegano merupakan sebuah citra digital yang dimana citra tersebut telah disisipi pesan. Citra stegano hampir sama tampilannya dengan citra cover. Citra stegano dapat dilihat pada gambar 2.

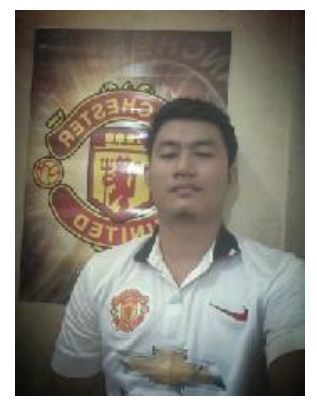

Gambar 2.Citra Stegano

Proses Extraction Berdasarkan Dynamic Cell Spreading. Langkah-langkah yang dilakukan dalam proses extraction adalah sebagai berikut:

1. Input steganoimage (citra yang telah menyimpan pesan)

2. Inputkan kunci ekstrasi, nilai biner karakter-karakter kunci di XOR. Hasil akhir proses XOR dijadikan sebagai nilai kunci pada proses ekstraksi.

3. Proses ekstraksi pesan

a. Input nilai pembangkit bilangan pengacak

b. Lakukan proses pengacakan posisi pixel berdasarkan nilai bilangan pengacakan yang dihasilkan (prosesnya sama seperti pada proses embedding)

c. Petakan posisi pixel hasil pengacakan (prosesnya sama seperti pada proses embedding)

d. Konversikan nilai-nilai pixel citra hasil pengacakan ke biner dengan menggunakan apliaksi matlab.

e. Ambil 8 bit dari setiap elemen warna pixel-pixel hasil pengacakan (delapan bit ini adalah kunci stegano yang telah disertakan pada proses penyembunyian pesan)

f. Cek apakah nilai 8 bit tersebut sesuai dengan nilai biner hasil akhir proses XOR karakter-karakter kunci atau tidak, apabila tidak maka proses ekstraksi ditolak, jika sama maka proses ekstraksi diteruskan.

g. Ambil bit-bit paling akhir yang dimulai dari posisi bit ke-9 sebanyak 8 bit kemudian konversi ke simbol atau karakter.

h. Lakukan proses pengambilan bit-bit paling akhir seperti pada langkah g di atas dengan kelipatan 8 (karena jumlah bit setiap karakter adalah 8 bit) hingga ditemukannya karakter penanda akhir pesan.

i. Apabila karakter penanda telah ditemukan, maka proses pengambilan bit-bit terakhir selesai yang menandakan bahwa pesan utama yang disembunyikan telah selesai diekstraksi dari stegano image.

Berikut ini contoh proses extraction berdasarkan dynamic cell spreading, dimana pada proses ini akan dilakukan pengungkapan data teks yang terdapat didalam citra stegano. Proses ini akan memisahkan data teks dengan citra

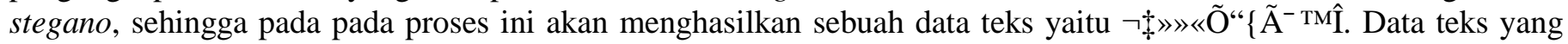
dihasilkan dari proses extraction masih berupa ciphertext yang tidak dimengerti maknanya, maka selanjutnya perlu dilakukan proses dekripsi untuk mengetahui pesan atau data teks yang sebetulnya. 
Proses Dekripsi Berdasarkan Hill Cipher. Proses yang dilakukan dalam dekripsi pesan (pengubahan ciphertext menjadi plaintext) dilakukan dengan langkah-langkah berikut :

1. Siapkan teks (cipertext) yang akan didekripsi yang mungkin berupa simbol, huruf ataupun teks

2. Siapkan kunci yang akan digunakan. Kunci yang digunakan sama seperti kunci yang digunakan pada saat melakukan proses enkripsi. Hanya saja dalam proses dekripsi, kunci yang digunakan adalah invers dari kunci itu sendiri.

3. Lakukan pengubahan teks (ciphertext) menjadi angka desimal berdasarkan tabel ASCII

4. Lakukan proses Dekripsi data teks (ciphertext) dengan menggunakan metode hill cipher dan modulus 256

5. Dari proses dekripsi tersebut akan menghasilkan suatu output yaitu plaintext atau teks sebetulnya (teks sebelum dilakukan penyandian).

Berikut ini contoh proses dekripsi berdasarkan hill cipher, dimana pada proses ini akan dilakukan pengubahan ciphertext menjadi plaintext atau teks yang asli. Ciphertext yang akan didekripsi yaitu $\neg \ddagger » » \ll \tilde{O}^{\prime}\left\{\tilde{\mathrm{A}}^{-} \mathrm{TM} \hat{\mathrm{I}}\right.$ dan setelah dilakukan proses dekripsi, maka akan menghasilkan plaintext atau pesan asli yaitu MARTHINLAOLI.

Hasil Pengujian. Proses pengujian dalam penelitian ini adalah menguji kinerja aplikasi pada proses embedding. Pengujian ini dilakukan pada beberapa citra cover dan beberapa pesan dan akan diuji apakah ada perubahan yang terjadi pada citra hasil (stegano-image). Perubahan ini diukur berdasarkan perhitungan nilai Peak Signal to Noise Rasio (PSNR) dan nilai Mean Sequare Error (MSE) antar citra cover dan citra stegano. Hasil pengujian dapat dilihat pada tabel 1 dan tabel 2.

Tabel 1.Hasil Pengujian Embedding Berdasarkan Dynamic Cell Spreading (DCS)

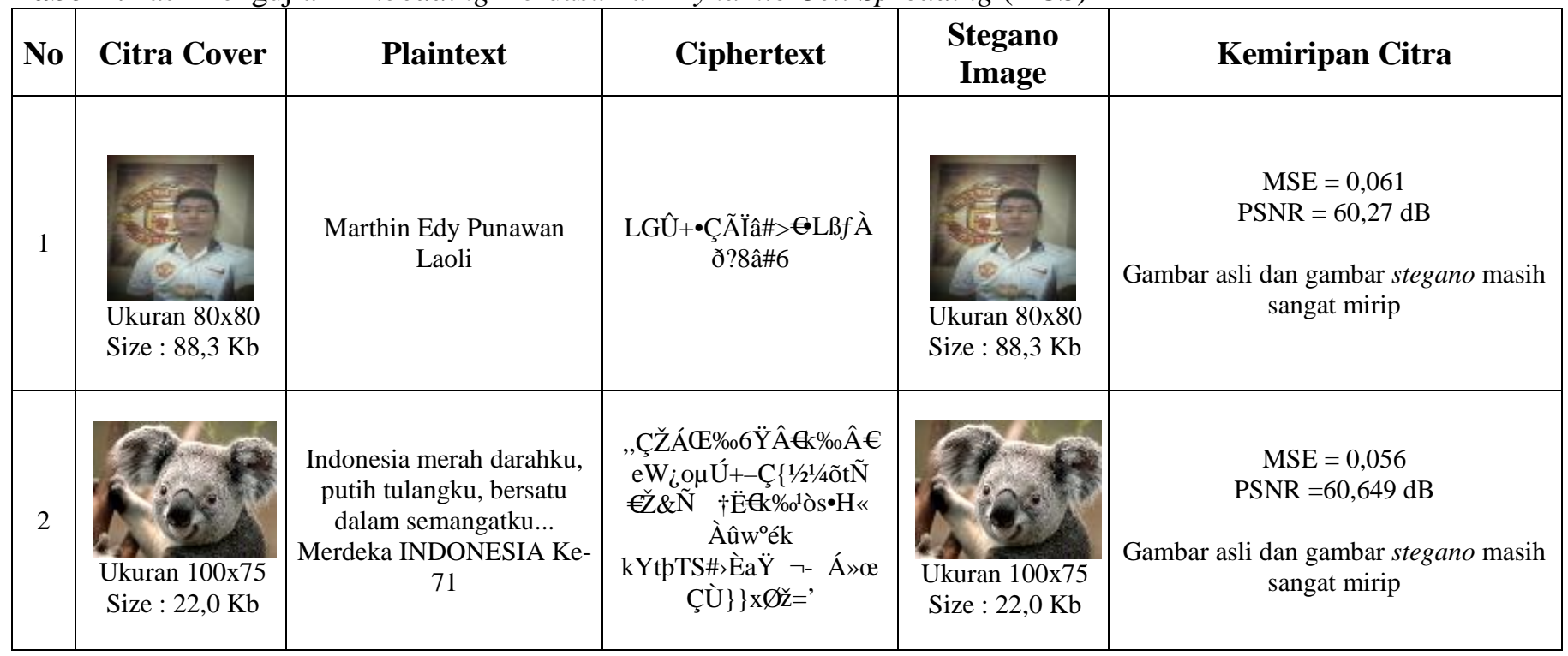

Tabel 2.Hasil Pengujian Extraction Berdasarkan Dynamic Cell Spreading (DCS)

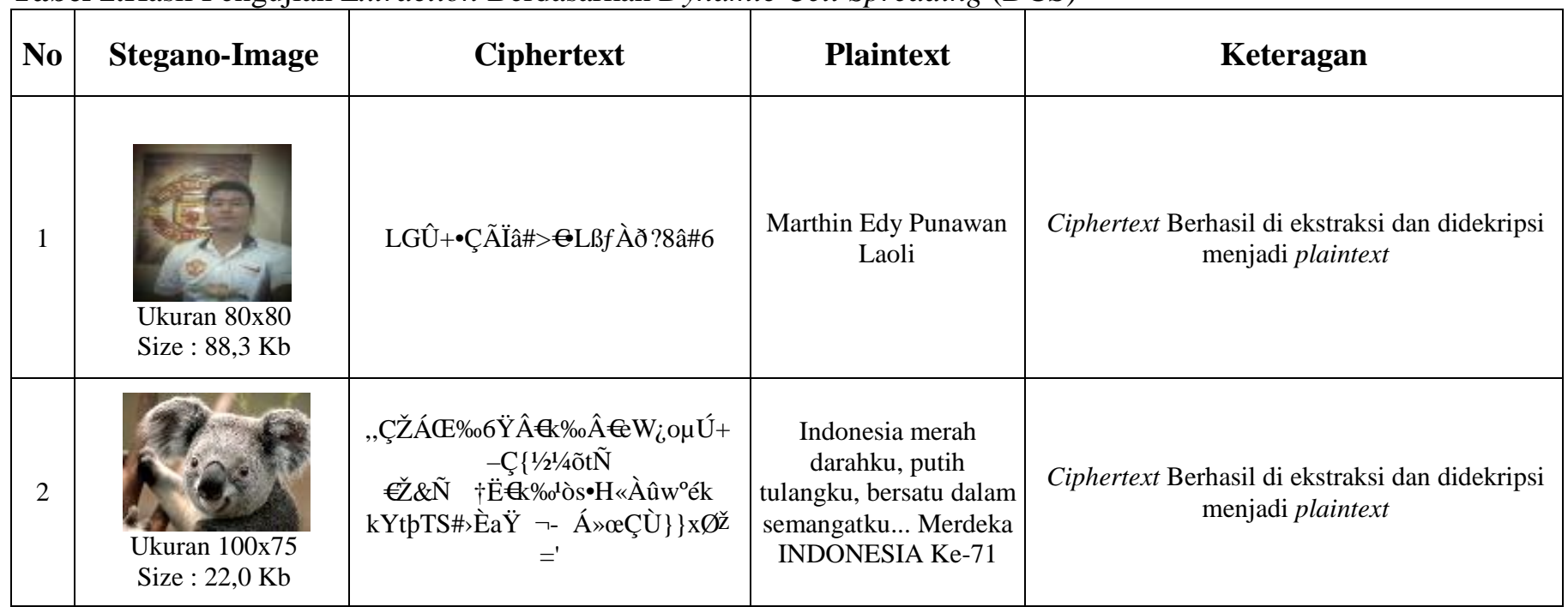




\section{KESIMPULAN}

1. Prosedur pengamanan data pada media citra digital dapat dilakukan dengan menggunakan kombinasi teknik kriptografi dan steganografi, dimana akan terdapat beberapa tahapan yang harus dilakukan yaitu proses enkripsi, proses embedding, proses extraction dan proses dekripsi.

2. Penerapan algoritma hill cipher untuk melakukan proses enkripsi terhadap karakter-karakter pesan untuk menghasilkan ciphertext, dilakukan dengan beberapa langkah utama yaitu :

a. Melakukan proses pengelompokkan karakter-karakter pesan menjadi beberapa kolom, dimana setiap kolom akan berisi tiga karakter pesan.

b. Melakukan perkalian matriks antara karakter pesan dengan kunci kriptografi yang digunakan.

c. Nilai-nilai yang dihasilkan dari proses perkalian matriks tersebut akan dimodulasikan, sehingga hasil akhir dari proses modulasi merupakan ciphertext.

Penerapan metode dynamic cell spreading untuk menyembunyikan bit-bit pesan ke dalam citra digital, dilakukan beberapa langkah utama yaitu :

a. Melakukan proses pengacakan pixel-pixel citra cover, kemudian hasil pengacakan tersebut dipetakan menjadi pixel citra cover yang disimpan di dalam buffer memory.

b. Proses penyembunyian bit-bit pesan pada citra digital dilakukan dengan mengganti bit-bit paling akhir (leas significant bit) setiap nilai pixel citra yang telah teracak dan tersimpan di dalam buffer memory dengan bit-bit pesan yang akan disembunyikan.

c. Nilai-nilai pixel hasil penggantian ini akan dipetakan menjadi citra baru (stegano image)

3. Perancangan aplikasi penyembunyian teks terenkripsi pada citra digital merupakan langkah yang memberikan dampak positif dalam mengamankan data teks, dimana dampak posisif tersebut berupa kemudahan dan efektifitas waktu yang dipergunakan dalam melakukan proses penyandian dan penyembunyian data teks pada citra, kelemahannya adalah bila perubahan bit-bit pixel citra cover terlalu banyak, maka akan berdampak pada perubahan penurunan kualitas citra hasil (stegano image).

\section{DAFTAR PUSTAKA}

Agus Wibowo dan Fachroni Akbar, Diagram Alir Perancangan Sistem, 2009. Jurnal.KOM, Vol 2, No.5.

Deni Mahdiana, 2011. Analisa dan Perancangan Sistem Informasi Pengadaan Barang Dengan Metodologi Berorientasi Obyek", Telematika MKOM, Vol.3 No.2.

Desi Lilyani, 2014. Implementasi Steganografi Pada Citra Digital Dengan Menggunakan Metode Dynamic Cell Spreading, Pelita Informatika Budidarma, Volume : VI, Nomor : 1.

Dian Riski Nugroho, 2009. Penerapan Model Pembelajaran Kooperatif Tipe (Team Games Tournamen) TGT Terhadap Motivasi Siswa Mengikuti Pembelajaran Bola Voli Di Kelas X SMAN 1 Panggul Kabupaten Trenggalek, UNS JURNAL, Vol 3, No.2.

Edy Prasetyo Utomo, 2013. Analisa dan Perancangan Sistem Informasi Parkir Di Universitas Maria Kudus, Jurnal SIMETRIS, Vol 3, No 1.

Rahimah, 2014. Implementasi Penyembunyian dan Penyandian Pesan Pada Citra Menggunakan Algoritma Affine Cipher dan Metode Least Significant Bit, Pelita Informatika Budidarma, Volume : VI, Nomor : 1.

Sri Dharwiyanti dan Romi Satria Wahono, "Pengantar Unified Modeling Language (UML)", Ilmu Komputer.com.

Sulindawati dan Muhammad Fathoni, 2010. Pengantar Analisa Perancangan Sistem", Jurnal SAINTIKOM, Vol.9, No.2.

Abdul Kadir, 2013. Pengenalan Algoritma Pendekatan Secara Visual dan Interaktif Menggunakan Raptor”, Andi, Yogyakarta.

Dony Ariyus, 2006. Computer Security, Andi, Yogyakarta.

Drs. Suarga, M.Sc., M.Math., Ph.D., 2006. Algoritma dan Pemrograman, Andi, Yogyakarta.

Emy Setyaningsih, S.Si., M.kom, 2015. Kriptografi dan Implementasinya Menggunakan MATLAB, Andi, Yogyakarta.

Rahmat Priyanto, 2009. Visual Basic.NET 2008, Andi, Yogyakarta.

Rinaldi Munir, 2006. Kriptografi, Informatika, Bandung. 